\title{
Strategi Manajemen Coping Program Pembinaan Fisik Dan Mental Dalam Mempersiapkan Calon Taruna/Taruni Baru
}

\author{
Karjono $^{1 *}$, Tini Utami ${ }^{2}$, Evyana Diah Kusumawati ${ }^{3}$, Devi Kusumaningrum ${ }^{4}$ \\ ${ }^{1,2,3,4}$ Politeknik Bumi Akpelni Semarang, Jl. Pawiyatan Luhur II No.17, Bendan Duwur, \\ Kec. Gajahmungkur, Kota Semarang, Jawa Tengah 50235 \\ * Corresponding Author. *E-mail : karjono@akpelni.ac.id. Telp : 08164245608
}

\begin{abstract}
Abstrak
Stres pada taruna/taruni baru disebabkan kesulitan dalam melakukan penyesuaian diri dibidang akademik maupun non akademik. Binafital bagaian dari syarat wajib untuk taruna/taruni baru sebelum mereka dikatakan sebagai taruna/taruni. Tujuan dari penelitian ini adalah untuk mengetahui strategi manajemen coping program pembinaan fisik dan mental dalam mempersiapkan calon taruna/taruni baru Politeknik Bumi Akpelni. Metode penelitian yang digunakan adalah metode penelitian kualitatif berdasarkan observasi langsung kepada narasumber. Hasil penelitian menunjukkan manajemen coping stres diketahui bahwa subjek berjenis kelamin laki-laki 75,6 \% lebih banyak menggunakan problem focused coping dibandingkan menggunakan emotion focused coping 24,4 \%. Subjek berjenis kelamin perempuan $87 \%$ secara keseluruhan lebih menggunakan problem focused coping dibandingkan menggunakan emotion focused coping 23\%.

Kata Kunci: Manajemen Coping, Pembinaan, Fisik, Mental

Abstract

Stress on cadets/new cadets is caused by difficulties in making adjustments in academic and non-academic fields. Binafital is part of the mandatory requirements for new cadets / cadets before they are said to be cadets / cadets. The purpose of this study was to determine the coping management strategy of the physical and mental development program in preparing prospective cadets/new cadets at the Bumi Akpelni Polytechnic. The research method used is a qualitative research method based on direct observation to informants. The results showed that the management of stress coping showed that $75.6 \%$ male subjects used more problem focused coping than $24.4 \%$ emotion focused coping. Overall, $87 \%$ female subjects used problem focused coping more than $23 \%$ using emotion focused coping.
\end{abstract}

Keywords: Coping Management, Physical, Mental, Development

\section{PENDAHULUAN}

Stres pada taruna baru pada umumnya dapat disebabkan adanya kesulitan dalam melakukan penyesuaian diri di bidang akademik maupun sosial pada lingkungan sekitar, sehingga hal tersebut dapat mengurangi pengoptimalan kemampuan mahasiswa dalam melakukan pengembangan diri dibidang akademik 
maupun sosial. Permasalahan yang dimiliki oleh mahasiswa dibagi menjadi dua, yaitu masalah akademik dan masalah non akademik. Pada masalah akademik berkaitan dengan perencanaan studi, cara belajar, dan pengenalan aturan. Sedangkan pada masalah non-akademik berkaitan dengan penyesuaian diri terhadap lingkungan kampus, kesukaran dalam mencari teman, kesukaran dalam pengembangan diri, serta terdapat masalah pribadi lainnya (Adiwaty \& Fitriyah, 2015).

Binafittal (pembinaan fisik dan mental) merupakan syarat wajib bagi calon Taruna/Taruni Politeknik Bumi Akpelni yang baru mernasuki dunia perkuliahan setelah menyelesaikan pendidikannya di sekolah menengah atas. Dengan berbagai karakter bawaan masing-masing individu dan beragam budaya dari berbagai daerah menciptakan suasana baru di lingkungan kampus.sebuah peralihan situasi yang sangat berbeda, Mereka akan merasakan peralihan situasi yang sangat berbeda, dengan lingkungan tempat pendidikan yang berbeda, dulu mereka berada di lingkungan sekolah dan sekarang berada di perguruan tinggi dimana lebih banyak orang dan tenaga pengajar yang mereka temui, teman-teman baru, lingkungan tempat tinggal baru, dan jauh dari orang tua atau keluarga juga akan mempengaruhi situasi yang dihadapi mereka. Mereka harus menyesuaikan diri dengan situasi yang baru. Menghadapi suasana lingkungan baru adalah sumber potensial yang dapat menirnbulkan stress. Didukung Politeknik Bumi Akpelni yang mempunyai program pendidikan karakter dan kedisiplinan yang tinggi dan mempunyai aturan untuk merubah kebiasaan yang dijalankan sebelum masuk di kampus. Peralihan masa perkembangan juga cukup memberi warna dalam kehidupan mahasiswa. Tak heran jika banyak cerita yang tertoreh saat seseorang berada dimasa mahasiswa. Tantangan dan permasalahan yang banyak dihadapi mahasiswa tak jarang menimbulkan stress. Stress menurut (Lahey 2001, dalam Bullare et al., 2009) stress merupakan suatu keadaan yang tidak selera dan adanya ancaman yang tidak sehat yang terjadi pada seseorang.

Adanya berbagai tekanan pada masa orientasi Taruna/taruni menghadapi situasi baru, yang harus menuntut calon taruna/taruni untuk dapat menyusun strategi penyelesaian masalah. Setiap individu mempunyai strategi penyelesaian yang berbeda. Perbedaan tersebut terlihat dari strategi pemecahan masalah yang diambil. Salah satu bentuk penyelesaian masalah adalah penyelesaian permasalahan yang langsung pada pokok masalah biasa disebut dengan problem focused coping. Problem focused coping merupakan suatu usaha untuk mengatasi situasi permasalahan dengan cara mengatur atau mengubah masalah yang dihadapinya dan lingkungan yang menyebabkan terjadinya tekanan (Lazarus \& Folkman, 1984). Strategi problem focused coping ini akan membantu individu untuk menghadapi dan menyelesaikan masalah secara efektif. Menurut Scheier \& Carver (1985) Merujuk pada jurnal karakteristik pemuda sekarang adalah konsumtif dalam pemakaian.

Mahasiswa masa kini yang mengalami stres lebih besar dan merasa depresi dari masa sebelumnya. Stres yang sering dialami oleh mahasiswa merupakan stres akademik. Stres akademik diartikan sebagai keadaan individu yang mengalami tekanan hasil persepsi dan penilaian tentang stressor akademik, yang berhubungan 
dengan ilmu pengetahuan dan pendidikan di perguruan tinggi, (Govaerts \& Grégoire, 2004). Mahasiswa masa kini yang mengalami stres lebih besar dan merasa depresi dari masa sebelumnya, menurut studi nasional terhadap lebih dari 200.000 mahasiswa baru di lebih dari 400 perguruan tinggi (Pryor dkk dalam Santrock, 2011). Lantas menurut studi nasional yang dilakukan oleh Asosiasi Kesehatan Universitas Amerika terhadap lebih dari 90. 000 mahasiswa di 177 kampus mengungkapkan bahwa mahasiswa merasa tidak memiliki harapan, merasa kewalahan dengan hal-hal yang harus mereka lakukan, mengalami kelelahan mental, sedih, dan merasa depresi (Santrock, 2011). Mahasiswa baru pada dasarnya dituntut untuk lebih aktif, baik aktif di organisasi maupun kegiatan-kegiatan lain yang mendukung tugas akademik maupun non akademik sebagai seorang mahasiswa (Siti \& Sukami dalam Adiwaty \& Fitriyah, 2015). Selain itu, banyak kegiatan belajar yang harus dimiliki oleh mahasiswa, seperti pemilihan cara belajar, pengaturan waktu belajar, mengikuti kuliah secara teratur, memilih mata kuliah yang sesuai, mempelajari buku-buku baru, mengkaji bermacam teori dan penelitian, membuat laporan tertulis, dan sebagainya (Sudrajat dalam Rahmi, 2013). Tuntutan-tuntutan yang terdapat di kehidupan mahasiswa tersebut, baik yang berasal dari luar diri maupun dalam diri menuntut untuk mampu dihadapi dengan lebih dewasa, bertanggung jawab, kuat, dan tangguh. Apabila mahasiswa baru mengalami kegagalan dalam mengatasi berbagai macam tuntutan tersebut dan gagal melakukan penyesuaian terhadap kejadian-kejadian yang menekan akan menyebabkan munculnya depresi maupun stres dalarn diri mahasiswa (Fisher dalam Susilowati \& Hasanat, 2011).

Menurut Lazarus \& Folkman (dalarn (Smet, 1994), manajemen coping adalah suatu proses dimana individu mencoba untuk mengelola jarak yang ada antara tuntutan-tuntutan (baik itu tuntutan yang berasal dari individu maupun tuntutan yang berasal dari lingkungan) dengan sumber-sumber daya yang mereka gunakan dalam menghadapi situasi stressfll. Folkman \& Moskowitz (2007) mengartikan strategi coping sebagai perubahan pernikiran dan perilaku yang digunakan oleh seseorang yang dalam menghadapi tekanan dari luar maupun dalam yang disebabkan oleh transaksi antara seseorang dengan lingkungannya yang dinilai sebagai stressor copingini nantinya akan terdiri dari upaya-upaya yang dilakukan untuk mengurangi keberadaan stressor. Lazarus \& Folkman (dalam Smet, 1994) membedakan coping stres menjadi dua jenis, yaitu emotion focused coping (coping yang berorientasi pada emosi dan problem focused coping (coping yang berorientasi pada masalah). Studi yang lain mengartikan definisi Coping adalah individu dari semua umur mengalami stres dan mencoba untuk mengatasinya. Karena ketegangan fisik dan emosional yang menyertai stres menimbulkan ketidaknyamanan, seseorang menjadi termotivasi untuk melakukan sesuatu untuk mengurangi stres. Hal-hal yang dilakukan bagian dari coping Garmezy, Rutter dan Lazarus (dalam Wardani, 2014) coping adalah proses dimana seseorang mencoba untuk mengatur perbedaan yang diterima antara demands dan resources yang dinilai dalam suatu keadaan yang stressful. Menurut Lazarus \& Folkman, (1984) mendefenisikan coping sebagai segala usaha untuk mengurangi stres, yang merupakan proses pengaturan atau tuntutan (eksternal maupun internal) 
yang dinilai sebagai beban yang melampaui kemampuan seseorang. Menurut Garrity dan Marx (dalam Caltabiano \& Sarafino (2002) menambahkan bahwa coping adalah proses dimana individu melakukan usaha untuk mengatur (management) situasi yang dipersepsikan adanya kesenjangan antara usaha (demands) dan kemampuan (resources) yang dinilai sebagai penyebab munculnya situasi stres. Menurut Theorell dan Rahe (dalam Caltabiano \& Sarafino (2002) usaha coping sangat bervariasi dan tidak selalu dapat membawa pada solusi dari suatu masalah yang menimbulkan situasi stres. Individu melakukan proses coping terhadap stres melalui proses transaksi dengan lingkungan, secara perilaku dan kognitif. Lazarus \& Folkman (1984) mendefinisikan coping sebagai berikut: "constantly changing cognitive and behavioral efforts to manage specificestenal and internal demands that are apprasaid as taxing or exceeding the resources ofperson." Berdasarkan penjelasan diatas, dapat disimpulkan bahwa coping merupakan cara pandang dan tingkah laku yang secara konstan berubah untuk mengatur tuntutan ekstemal dan internal yang dinilai membebani atau melebihi sumber daya dari seseorang. Tindakan ini bisa bersifat action-oriented maupun intra psikis, keduanya berusaha untuk mengatur, menguasai, mentoleransi, ataupun mengurangi muatan dari lingkungan yang mengakibatkan stres. Hal ini terlihat dari pemyataan "constantly changing and specific demands". Kemudian ditekankan juga adanya perbedaan antara coping dengan tingkah laku adaptif yang otomatis dengan membatasi coping pada tuntutan yang dinilai membebani ataupun melebihi surnber daya seseorang. Maka, segala bentuk tingkah laku maupun pemikiran yang tidak mernbutuhkan usaha tidak dapat digolongkan sebagai coping. Selanjutnya pernyataan bahwa manajamen coping merupakan "usaha untuk rnengatur" juga memperjelas bahwa segala tindakan dan pemikiran seseorang dalam menghadapi situasi yang dinilai melebihi sumber dayanya merupakan coping, sebaik atau seburuk apapun hasilnya. Terakhir, dengan rnenggunakan kata "manage", coping juga dapat mengandung, mengurangi, menghindari, mentoleransi dan menerima kondisi yang mengakibatkan stres serta rnenguasai lingkungan. Dengan kata lain coping adalah usaha individu baik secara kognitif rnaupun tingkah laku mengelola tuntutan internal maupun eksternal yang dinilai rnelebihi kapasitas kemampuan individu dari situasi yang menekan. Coping merupakan pencarian cara untuk memperkecil dampak dari tekanan-tekanan yang dialami oleh individu.

Cara individu menangani situasi yang mengandung tekanan ditentukan oleh sumber daya individu yang meliputi : (a) kesehatan fisik/energi, merupakan yang penting karena selama dalam usaha mengatasi stres individu dituntut untuk mengerahkan tenaga yang cukup besar; (b) keyakinan atau pandangan positif, keyakinan menjadi sumber daya psikologis yang sangat penting, seperti keyakinan akan nasib yang mengerahkan individu pada penilaian ketidakberdayaan (helplessness) yang akan menurunkan kemampuan strategi coping tipe:problemsolving focused coping; (c) keterampilan memecahkan masalah, keterampilan ini meliputi kemampuan untuk mencari informasi, menganalisa situasi, mengidentifikasi masalah dengan tujuan untuk menghasilkan alternatif tindakan, kemudian mempertimbangkan altenatif tersebut sehubungan dengan hasil yang ingin dicapai, dan pada akhirnya melaksanakan rencana dengan melakukan suatu 
tindakan yang tepat; (d) keterampilan sosial, keterampilan ini meliputi kemampuan untuk berkomunikasi dan bertingkah laku dengan cara-cara yang sesuai dengan nilai- nilai sosial yang berlaku dimasyarakat; (e) dukungan sosial,dukungan ini meliputi dukungan pemenuhan kebutuhan informasi dan emosional pada diri individu yang diberikan oleh orang tua, anggota keluarga lain, saudara, teman, dan lingkungan masyarakat sekitarnya dan (f) materi dukungan ini meliputi sumber daya berupa uang, barang barang atau layanan yang biasanya dapat dibeli.

Internet, sebuah kebiasaan melineal ketika para pengguna bisa memanfaatkan media baik maka akan munculnya positif sebaliknya, interaksi sosial masyarakat berangsur berkurang karena priorotas online lebih diutamakan. Sesuai dengan Keputusan Direktur Politeknik Bumi Akpelni Nomor : Kp ts.I50/PBA/ I.VIII/2021 pelaksanaan kegiatan Binafital Taruna Politeknik Bumi Akpelni. Pada penelitian ini fokus pertama menggali dan mengembangkan potensi yang selama ini dimiliki calon taruna/taruni yang sebelumnya mempunyai kebiasaan penggunaan internet secara berlebihan akhimya menjadi kecanduan, awal timbulnya stres disaat memulai kegiatan binafital di Politeknik Bumi Akpelni, sehingga harapan peneliti bisa membangun peradaban Taruna/Taruni yang memiliki etika yang baik dan merubah yang konsumtif menjadi produktif. Kedua menciptakan strategi meliputi merubah mindset calon Taruna/Taruni dengan memulai tindakan langsung, meningkatkan pola pikir yang positif, dan menghadapi masalah dengan cara-cara yang bijaksana. Ketiga adalah Perencanaan, untuk berpikir mengenai bagaimana menghadapi stressor dan membuat strategi yang akan dilakukan, juga memikirkan bagaimana cara untuk mengurangi masalah dan bagairnana mengatasi masalah.

\section{METODE PENELITIAN}

Dalam studi penelitian program pembinaan fisik dan mental dalam mempersiapkan calon taruna/taruni baru Politeknik Bumi Akpelni ini, penggunaan metodologi merupakan suatu langkah yang harus ditempuh agar data-data yang sudah terseleksi dapat terjawab secara valid, reliable dan obyektif, dengan tujuan dapat ditemukan, dibuktikan dan dikembangkan suatu pengetahuan, sehingga dapat digunakan untuk memahami, memecahkan dan mengantisipasi masalah.

\section{Objek Penelitian, Lokasi Dan Waktu Penelitian}

Objek penelitian ini adalah Calon Taruna/Taruni Baru Politeknik Bumi Akpleni yang masih menjalani program Binafital Tahun ajaran 2021/2022, antara lain: Penelaahan terhadap regulasi program rutin Binafital untuk Calo, Taruna/Taruni Baru Politeknik Bumi Akpleni persiapan Taruna Taruni, Penyerapan informasi dan masukan dari Calon Taruna/Taruni Binafital, Materi yang dibutuhkan dari program tersebut adalah kewenangan dan kelembagaan (regulasi, kewenangan, kelembagaan), permasalahan yang dihadapi di lapangan.

Lokasi Penelitian dilaksanakan di Politeknik Bumi Akpelni Semarang, waktu pelaksanaan kegiatan penelitian program pembinaan fisik dan mental dalam 
mempersiapkan calon taruna/taruni baru Politeknik Bumi Akpelni dialokasikan waktu selama 60 hari (2 bulan) kalender.

\section{Sumber Data, Teknik Pengumpulan Data dan Analisis Data}

Sumber Data Primer, yaitu hasil wawancara, penyebaran angket-angket daftar pertanyaan (kuesioner) dan observasi (identifikasi permasalahan Calon Taruna/Taruni. data sekunder diperoleh melalui segala informasi yang telah dihimpun oleh berbagai pihak dalam bentuk data tersaji seperti buku/ laporan, tabel, grafik, data statistik dan lain sebagainya (Wibowo, 2021). Sumber data sekunder yaitu berupa produk peraturan dari PBA dalam penyelenggaraan Binafital. Teknik pengumpulan data meliputi: (1) wawancara, yaitu mengadakan tanya jawab secara lisan dengan responden/pihak-pihak yang terkait di dalamnya, (2) Kuisioner dengan responden peserta Binafital, kuesioner adalah salah satu metode survei dalam melakukan penelitian yang dipakai untuk mengumpulkan data dari responden(Pertiwi et al., 2021). (3) Studi pustaka, yaitu dilakukan dengan cara menelaah buku-buku, perundang- undangan, dokumen, dan buku-buku literature, (4) Diskusi, dilakukan pada setiap tahapan penelitian, agar mempunyai kesempatan yang cukup untuk mempelajarinya.

Teknik analisa data yang digunakan adalah analisis model interaktif yang terdiri dari 3 komponen analisis yaitu reduksi data, sajian data dan penarikan kesimpulan, sebagai berikut: Penelitian kualitatif harus memenuhi keabsahan data Lincoln (1980). Oleh karena itu penelitian ini mengunakan kriteria, yakni: (a) Derajat Kepercayaan (Credibility). Penerapan kriteria derajat kepercayaan dimaksud sebagai pengganti konsep validitas internal dari penelitian non kualitatif. Untuk mencapai derajat kepercayaan dimaksud, maka proses analisis data (pengumpulan, reduksi, penyajian dan kesimpulan). (b) Keteralihan (Transferability, merupakan upaya membangun persamaan persepsi antara Peneliti dengan pembaca atau pengguna. (c) Ketergantungan (Dependability), dalam istilah konvensional disebut dengan reliabilitas, yang merupakan syarat bagi validitas. (d) Kepastian (Confirmabilitys), Kriteria kepastian dalam penelitian ini dimaksudkan hasil penelitian tidak bisa atau menyimpang dari realita yang ada, rumusan masalah dan tujuan penelitian.

\section{HASIL DAN PEMBAHASAN}

Peneliti menguraikan gambaran subyek pelaksanaan penelitian, Responden dalam penelitian ini yaitu calon Taruna/Taruni dari Prodi Nautika,Teknika,Katatalaksanaan dan kepelabuhanan , Tarnsportasi Laut. Angkatan 57 berjumlah 237 terdiri Taruna sebanyak 213 dan Taruni 24, di Politeknik Bumi Akpekni. Gambaran sekilas berdasarkan demografi yaitu, jenis kelamin, asal usul, sekolah. BINAFITAL sebutan ini agaknya kurang bersahabat di dengar oleh masyarakat, Kampus kami Binafital adalah Program wajib yang harus di lalui oleh Taruna/Taruni Baru Sesuai dengan Keputusan Direktur Politeknik Bumi Akpelni Nomor : Kpts.150/PBA/I.VIII/2021 pelaksanaan kegiatan Binafital Taruna Politeknik Bumi Akpelni, fokus permasalahan pertama menggali dan mengembangkan potensi yang selama ini dimiliki calon Taruna/taruni yang 
sebelumnya mempunyai kebiasaan penggunaan internet secara berlebihan akhirnya menjadi kecanduan, awal timbulnya stres disaat memulai kegiatan binafital di Politeknik Bumi Akpelni, sehingga harapan peneliti bisa membangun peradaban Taruna/Taruni yang memiliki etika yang baik dan merubah yang konsumtif menjadi produktif. Penggunaan internet masalah psikologis ini juga dapat terjadi pada orang dewasa. Apalagi selama musim pandemi Covid-19 angakatan 57 Politeknik Bumi Akpelni gadget dipakai dari bangun tidur sampai akan tidur lagi aktifitas sekolah On-line dll.

Saat ini zaman sudah semakin canggih, kehadiran gadget dan teknologi telah menjadi kebutuhan utama. Tidak hanya sebagai alat penunjang, seperti komunikasi saja. Tapi juga membantu berjalannya aktivitas lain (Astriawati et al., 2020). Kehadiran dari teknologi satu tetapi bisa memenuhi semua kebutuhan tidak hanya memberikan dampak positif saja. Tapi ada cukup banyak dampak negatif yang sering dialami oleh beberapa pengguna.Terutama masalah dalam psikologis. Tidak hanya akan menimpa pada anak-anak saja. Tapi masalah psikologis ini juga dapat terjadi pada orang dewasa. Apalagi gadget dipakai dari bangun tidur sampai akan tidur lagi.Hal tersebut tergantung bagaimana anda menyikapi dan memilihnya. Pertama mengurangi interaksi Dengan Orang salah satu dampak psikologis menggunakannya terlalu sering akan membuat interaksi di dunia nyata menjadi berkurang komunikasi bersama keluarga dan orang terdekat menjadi berkurang. Dapat membentuk gangguan anti sosial secara tidak langsung jika sudah terbiasa, dari usia anak-anak. Kedua Malas Melakukan Aktivitas Keseharian terlalu asyik bermain dengan gadget dan malas bergerak. Hal tersebut tentunya akan menyebabkan cukup banyak pekerjaan tertunda. Generasi muda juga akan mengalami kerugian di masa mendatang. Anak-anak juga akan malas dalam membaca dan menulis. Mereka akan lebih asyik melihat gambar-gambar yang menarik dan menganggap membaca atau menulis menjadi hal yang membosankan. Mampu mempengaruhi keterampilan menulis, karena koordinasi motorik menjadi kurang bagus efeknya adalah tulisan tangan mereka akan menjadi jelek. Ketiga waktu tidur/ istirahat berkurang saat bermain gadget, apalagi sebelum tidur maka dapat membuat waktu tidur berkurang. Hal tersebut akan memicu timbulnya jenisjenis dari gangguan tidur. Secara tidak langsung memiliki efek yang buruk, terutama pada kesehatan tubuh. Karena umumnya orang dewasa tidur minimal 6-8 jam dan anak-anak 9-11 jam setiap harinya. Keempat menumbuhkan Sikap Egosentris Sikap egosentris ini merupakan sikap yang tidak baik, terutama di lingkungan sosial. Penggunaan berlebihan , akan terbiasa tidak peduli dengan orang lain secara tidak langsung. Selain itu akan muncul rasa empati yang kurang terhadap lingkungannya. Kelima Memicu Berkembangnya Konsumerisme, Dampak psikologis yang lain, dengan munculnya budaya konsumerisme. Konsumerisme ini berkaitan dari segi ekonomi dan sering terjadi pada anak remaja masa kini. Sehingga hal tersebut masuk dalam salah satu gangguan psikologis pada anak remaja. Karena kemunculan nya juga terjadi dari keinginan para remaja yang terus menerus untuk membeli gadget terbaru dan mengikuti trend. Dengan begitu dapat menyebabkan anak-anak remaja hidupnya lebih boros, terutama pengeluaran operasional berupa gadget. Biaya ini juga terdiri dari service hand phone, pulsa, 
aksesoris gadget dan yang lainnya. Mampu mempengaruhi gaya hidup, menjadi egois dan suka pamer dengan teman-temannya. Sifat ini akan merusak tingkat konsumtif dan seharusnya tidak dimiliki oleh anak-anak remaja yang masih duduk di bangku sekolah. Karena anak-anak biasanya belum tentu dapat memilih salah satu informasi secara benar. Keenam, Konsentrasi Menurun Saat anda menggunakan smartphone atau gadget terlalu sering. Dapat menyebabkan konsentrasi semakin menurun. Baik untuk bekerja atau untuk belajar setiap harinya. Konsentrasi seseorang juga menjadi lebih singkat dan membuatnya tidak peduli pada lingkungan sekitar. Pada anak-anak mereka akan lebih senang menghabiskan waktu bermain gadget dan berimajinasi dibandingkan belajar. Seperti bermain game dan kebiasaan ini mampu merusak kemampuan konsentrasi meskipun tidak secara langsung. Ketujuh. Perkembangan Anak terganggu hal ini biasa terjadi pada anak-anak dan orang tua yang sudah cukup kecanduan gadget. Maka dapat menyebabkan perkembangan anak dan pertumbuhannya menjadi bermasalah. Anak sendiri membutuhkan stimulus dari setiap orang tua terdekat. Begitu juga lingkungan supaya dapat mengembangkan kemampuan bersama yang telah dimiliki. Tapi jika orang tua sudah terlalu asik bermain gadget, maka orang tua juga tidak akan merespons kebutuhan anak dengan cepat. Pengawasan dan penggunaan gadget juga masih membutuhkan pengawasan ekstra. Jika diawasi, maka perkembangan anak akan lebih membaik dan prestasi mereka di sekolah tidak akan menurun. Anak tidak akan sampai mengalami gangguan perkembangan selama pengawasan tetap dilakukan dengan benar. Kedelapan, Memicu Penyakit Mental Penggunaan gadget yang tidak teratur, maka dapat menyebabkan gejala penyakit mental. Terutama pada anak-anak remaja yang sedang dalam masa pertumbuhan. Mulai dari depresi, peningkatan laju kecemasan, gangguan perhatian, bipolar, autisme dan gangguan mental lainnya. Stress dan depresi juga akan terjadi pada anak-anak jika terlalu sering menggunakan gadget. Stres sendiri dipicu dari permainan game yang dilakukan pada gadget milik mereka sendiri. Dengan begitu akan menyebabkan kondisi mental anak menjadi terganggu.Kesembilan, Sosialisme dengan sekitar berkurang akibat penggunaan gadget yang berlebihan, maka dapat menimbulkan sikap individualism tinggi. Dampak tersebut akan terjadi pada anak yang memiliki sifat apatis kepada sesamanya. Selain itu dapat menjadi tempat untuk berbuat curang. Dengan adanya gadget, saat ulangan maka dapat digunakan untuk menjawab soal ulangan. Mereka akan mencari jawaban melalui contekan, browser, catatan, contekan dari galeri foto, meminta jawaban dari teman sekelas melalui SMS dan yang lainnya. Melalui gadget ini, anak-anak akan mendapatkan jawaban lebih mudah. Hanya dalam beberapa detik saja, jawaban sudah dapat ditemukan.

Melalui kegiatan bimbingan Fisik dan mental Politeknik Bumi Akpelni mempunyai tujuan mempunyai manajemen pembatasan penggunaan Gadget dan Internet, pada masa tersebut selama dua bulan penuh kebiasaan mereka penggunaan gadget secara berlebihan akan berdampak secara langsung tingakat stress, Dari kesembilan aspek tersebut subyek Calon Taruna mempunyai perbedaan dalam mengambil Manajemen coping stres diketahui bahwa subjek berjenis kelamin lakilaki 75,6 \% lebih banyak menggunakan Problem focused coping, dibanding menggunakan Emotion focused coping 24,4 \%. Yang berjenis kelamin perempuan 
87\% secara keseluruhan lebih menggunakan problem focused coping, dibanding menggunakan Emotion focused coping 23\%. Pada perempuan perempuan menggunakan strategi Problem Focus Coping pada aspek penyelesain masalah yang terencana paling tinggi 56,67, dan laki - laki yang berjenis kelamin laki- laki menggunakan strategi Problem Focus Coping pada aspek penyelesain masalah yang terencana juga paling tinggi 48,75 \%. Sedangkan subjek yang berjenis kelamin perempuan menggunakan strategi Emotion Focus Coping pada aspek pengendalian diri paling tinggi 65,00\%, berjenis kelamin laki-laki menggunakan strategi Emotion Focus Coping pada aspek pengendalian diri juga paling tinggi 81,25 \%.

Penelitian terdahulu oleh Sinaga (2005) diketahui mahasiswa yang mengalami stres sebanyak 84,3\% melakukan problem focused coping dengan mempelajari cara-cara atau keterampilan-keterampilan yang baru, yang diyakini dapat mengubah situasi stres dan 15,65\% melakukan emotional focused coping yaitu perilaku yang cenderung mengatur emosi atau mengatasi tekanan emosionalnya, berkaitan dengan situasi yang terjadi. Dan dari hasil penelitian Lasmono\&Pramadi (2003) menyebutkan bahwa pada budaya jawa problem focused coping lebih sering digunakan untuk mengatasi tekanan/masalah. Hal ini terlihat bahwa lebih banyak subjek yang melakukan problem focus coping dibandingkan subjek yang melakukan emotion focused coping.

Billings \& Moos (1984) menyatakan bahwa orang yang cenderung menggunakan strategi terfokus masalah situasi stres menunjukan tingkat stress yang lebih rendah. Coping yang beorientasi pada masalah digunakan untuk mengatasi stresor. Individu akan cenderung menggunakan strategi ini bila dirinya yakin akan dapat mengubah situasi.Tergantung oleh tingkat stres yang dirasakan seseorang dan cara subjek mengatasi stress atau masalahnya. Setiap individu menangani situasi yang mengandung tekanan ditentukan dari daya individu yang meliputi: (a) kesehatan fisik individu; (b) keyakinan atau pandangan positif;( c) keyakinan individu dalam menyelesaikan masalah; (d) kemapuan individu dalam berkomunikasi dengan lingkungan masyakrakat yang lebih luas; (e) dukungan sosial dari orang tua, teman, dan lingkungan masyarakat; (f) materi pendukung seperti uang atau barang yang dapat dibeli. Lazarus \& Folkman (1984) menyatakan bahwa pengelompokan perilaku coping menjadi dua yaitu: Dikaitkan dengan Problem Focus Coping meliputi; (a) konfrontasi yaitu berusaha keras pada sikapnya, menolak untuk berubah dan berusaha untuk mengubah keyakinan orang lain; (b) Mencari dukungan sosial yaitu percaya pada teman dan keluarga untuk sarana dan dukungan; (c) Penyelesaian masalah yang terencana yaitu mencari pilihan dalam perilaku objektif, mempertimbangkan berbagai kemungkinan sebelum mengambil keputusan. Kemudian dikaitakan dengan Emotion Focus Coping: (a) Pengendalian diri yaitu bereaksi tenang tanpa menunjukkan emosi; (b) Menjaga jarak yaitu menarik diri, berusaha bermain dibawah atau mengabaikan kejadian yang penuh tekanan; (c) Penilain kembali secara positif yaitu berusaha untuk memandang situasi dari perspektif yang berbeda, mencoba untuk mencari penyelesaian; (d) Menerima tanggung jawab yaitu mengenali peran personal dalam kejadian, mencoba untuk belajar dari kesalahan; (e) Lari atau menghindar yaitu 
menolak atau menerima perubahan dengan menghindari situasi, kadang-kadang lari atau menghindar yang mengarah pada kejadian tidak menyenangkan.

\section{SIMPULAN}

Berdasarkan hasil analisis dapat diketahui bahwa didapatkan dari tiap strategi dengan presentase manajemen coping stres diketahui bahwa subjek berjenis kelamin laki-laki $\quad 75,6$ \% lebih banyak menggunakan Problem focused coping, dibanding menggunakan Emotion focused coping 24,4 \%. Yang berjenis kelamin perempuan $87 \%$ secara keseluruhan lebih menggunakan problem focused coping, dibanding menggunakan Emotion focused coping 23\%. Sedangkan untuk aspek penyelesain masalah yang terencana paling tinggi pada perempuan menggunakan strategi Problem Focus Coping adalah 56,67\%, dan yang berjenis kelamin laki- laki menggunakan strategi Problem Focus Coping pada aspek penyelesain masalah yang terencana juga paling tinggi 48,75 \%. Sedangkan subjek yang berjenis kelamin perempuan menggunakan strategi Emotion Focus Coping pada aspek pengendalian diri paling tinggi 65,00\%, berjenis kelamin laki-laki menggunakan strategi Emotion Focus Coping pada aspek pengendalian diri juga paling tinggi 81,25 \%. Harapan peneliti bisa membangun peradaban Taruna/taruni yang memiliki etika yang baik dan merubah yang konsumtif menjadi produktif. Kedua menciptakan strategi meliputi merubah mindset calon Taruna/taruni dengan memulai tindakan langsung, meningkatkan pola pikir yang positif dan menghadapi masalah dengan cara-cara yang bijaksana. Ketiga adalah Perencanaan, untuk berpikir mengenai bagaimana menghadapi stressor dan membuat strategi yang akan dilakukan, juga memikirkan bagaimana cara untuk mengurangi masalah dan bagaimana mengatasi masalah.

\section{DAFTAR PUSTAKA}

Adiwaty, M. R., \& Fitriyah, Z. (2015). Efektivitas strategi penyesuaian mahasiswa baru pada proses pembelajaran di perguruan tinggi.(Studi pada UPN" Veteran” Jawa Timur). Neo-Bis, 9(2), 1-15.

Astriawati, N., Wibowo, W., \& Widyanto, H. (2020). Designing Android-Based Augmented Reality Application on Three Dimension Space Geometry. Journal of Physics: Conference Series. https://doi.org/10.1088/17426596/1477/2/022006

Billings, A. G., \& Moos, R. H. (1984). Coping, stress, and social resources among adults with unipolar depression. Journal of Personality and Social Psychology, 46(4), 877.

Bullare, F. B., Rathakrishnan, B., \& Ismail, R. (2009). Sumber Stres, Strategi Daya Tindak dan Stres Yang Dialami Pelajar Universiti (The Source of Stressor, Coping Strategies and Stress Experienced by University Students). Jurnal Kemanusiaan, 7(1).

Caltabiano, M. L., \& Sarafino, E. P. (2002). Health psychology: biopsychosocial interactions. An Australian perspective. John Wiley \& Sons. 
Folkman, S., \& Moskowitz, J. T. (2007). Positive affect and meaning-focused coping during significant psychological stress. The Scope of Social Psychology: Theory and Applications, 10, 193-208.

Govaerts, S., \& Grégoire, J. (2004). Stressful academic situations: Study on appraisal variables in adolescence. European Review of Applied Psychology, 54(4), 261-271.

Lazarus, R. S., \& Folkman, S. (1984). Stress, appraisal, and coping. Springer publishing company.

Lincoln, Y. S. (1980). Guba. E.(1985). Naturalistic inquiry. Beverly Hills: Sage. LincolnNaturalistic Inquiry1985.

Pertiwi, Y., Astriawati, N., Wibowo, W., \& Kristianto, L. (2021). Moodle Virtual Class Effectivity toward Cadets' Learning Motivation and Speaking Ability. Ethical Lingua: Journal of Language Teaching and Literature, 8(2), 378-383.

Rahmi, N. (2013). Hubungan Tingkat Stress dengan Prestasi Belajar Mahasiswa Tingkat II Prodi D-III Kebidanan Banda Aceh Jurusan Kebidanan Poltekkes Kemenkes NAD TA. 2011/2012. Jurnal Ilmiah STIKes U'Budiyah, 2(1).

Santrock, J. W. (2011). Masa perkembangan anak.

Scheier, M. F., \& Carver, C. S. (1985). Optimism, coping, and health: assessment and implications of generalized outcome expectancies. Health Psychology, 4(3), 219.

Smet, B. (1994). Psikologi Kesehatan (Terjemahan Kartono, K). Jakarta: PT. Gramedia Widiasarana.

Susilowati, T. G., \& Hasanat, N. U. (2011). Pengaruh terapi menulis pengalaman emosional terhadap penurunan depresi pada mahasiswa tahun pertama. Jurnal Psikologi, 38(1), 92-107.

Wardani, T. A. (2014). Pengaruh harapan dan coping stres terhadap resiliensi caregiver kanker.

Wibowo, W., \& Astriawati, N. (2021). Sistem Pendingin Tertutup Pada Mesin Diesel Tipe Diesel MAK 8M32 Sebagai Penggerak Utama Kapal Motor LIT ENTERPRISE. Jurnal POLIMESIN, 19(1), 28-34. 